九州大学学術情報リポジトリ

Kyushu University Institutional Repository

\title{
Pollution of Water and Agricultural Soils in Tuliem and Thanhtri Districts of Hanoi City, Vietnam - A Report
}

Tra, Ho Thi Lam

Laboratory of Soils, Faculty of Agriculture, Kyushu University

Manh, Nguyen Dinh

Faculty of Land and Water Resources Management, Hanoi Agricultural University

Hai, Do Nguyen

Faculty of Land and Water Resources Management, Hanoi Agricultural University

Egashira, Kazuhiko

Laboratory of Soils, Faculty of Agriculture, Kyushu University

https://doi.org/10.5109/24239

出版情報 : 九州大学大学院農学研究院紀要. 42 (3/4)，pp.509-521，1998-03. Kyushu University バージョン：

権利関係 : 


\title{
Pollution of Water and Agricultural Soils in Tuliem and Thanhtri Districts of Hanoi City, Vietnam - A Report
}

\author{
Ho Thi Lam Tra, Nguyen Dinh Manh*, Do Nguyen Hai*, and \\ Kazuhiko Egashira
}

\author{
Laboratory of Soils, Faculty of Agriculture, Kyushu University, \\ Fukuoka 812-8581, Japan, and *Faculty of Land and Water \\ Resources Management, Hanoi Agricultural University, Gialam, Hanoi, Vietnam. \\ (Received November 19, 1997 and accepted December 3, 1997)
}

\begin{abstract}
Limited information is available on the quality of water and agricultural soils in Tuliem and Thanhtri districts of Hanoi city. Based on the Vietnam standard for the quality of water and soils, 14 water and 22 soil samples in Thanhtri district, and 7 water and 14 soil samples in Tuliem district were collected and analyzed for the prescribed parameters. In comparison with the Vietnam standard for the quality of water and soils, quality of water and soils in Tuliem and Thanhtri districts was evaluated. Quality of water as agricultural use was as follows: $\mathrm{pH}$ was neutral; EC was between 0.18 and $0.59 \mathrm{dS} / \mathrm{m}$; COD was below the limit; no sample was over the limit value for $\mathrm{Zn}$, but one, three and two samples exceeded the limit values for $\mathrm{Cu}, \mathrm{Pb}$ and $\mathrm{Cd}$, respectively. Quality of agricultural soils was as follows: $\mathrm{pH}$ ranged from 5.40 to 7.00 ; all soil samples showed total $\mathrm{N}$ content below $0.25 \%$ and available $\mathrm{P}_{2} \mathrm{O}_{5}$ more than $20 \mathrm{mg} / \mathrm{kg}$; contamination of several heavy metals was indicated in soils around the manufacturing factory and in mud of the river bed, while contamination by $\mathrm{Cu}$ was in soil affected by agricultural chemicals.
\end{abstract}

\section{INTRODUCTION}

Hanoi is the capital of Vietnam. Population of Hanoi city is 2.25 million (Hanoi Statistical Office, 1996) and increasing at the annual rate of more than $2 \%$. The area of Hanoi city is $590 \mathrm{~km}^{2}$ and comprises 7 prefectures (Haibatrung, Badinh, Hoankiem, Dongda, Tayho, Caugiay and Thanhxuan) and 5 districts (Tuliem, Thanhtri, Donganh, Gialam and Socson). The rapid population growth, its concentration to Hanoi city, and rising living-standard have led to a substantial increase in the quantity and diversity of waste products, particularly municipal solid wastes and sewage sludge.

Tuliem and Thanhtri districts are located on the southwestern part of Hanoi city. The two districts have population of nearly one million. There are 22 factories in Thanhtri and Tuliem districts, what consume nearly 35,000 tons of coal and 2,000 tons of petrol per year. Most of them were built after 1954 and construction was concentrated in 1950-60 and 1970-80. Important factories are arranged chronologically:

1. Thuykhue leather factory in 1950.

2. Hanoi beer factory in 1955 .

3. Vandien phosphate factory in 1957.

4. Saovang rubber factory, Hanoi soap factory, and Hanoi tobacco factory in 1958.

5. Vandien battery factory in 1959 .

6. Caudien chemical factory in 1962. 
7. Caubieu plating factory in 1963.

8. Vandien engineering work in 1964.

9. Hanoi engineering work in 1965.

10. Hanoi paint factory in 1984.

11. Hanoi brick factory in 1986.

12. General paint factory in 1989.

In addition, Vandien cemetery dates from before 1954, and Thuongdinh dump dates from 1986.

Until recently people did not pay any attention to the waste water and solids. The equipments for trapping or treating chemically the factory waste were wrong. It is danger to crops, livestocks and human beings, because waste water and solids are directly discharged to environment.

After Vietnam government made the renewal policy (renovation) of economical development, explosions without city planning have produced a lot of problem, which lead to immediate causes for destruction of environment. Side by side with this, there is increase in motorization, which brings about consumption of much petrol.

In 1995, Hanoi Agricultural University started the program for survey of the pollution of agricultural water and soils in Hanoi city, which was sponsored by Hanoi Scientific and Environmental Office with following purposes: 1) estimation of actual quality of water provided for crop plants and aquatic products; 2) estimation of actual quality of agricultural soils in intensively cropped areas; and 3) as a first step clarification of the influence of industry and transportation on the quality of agricultural water and soils.

In the present report, activity of Hanoi Agricultural University in monitoring agricultural environments and the quality of water and agricultural soils in Tuliem and Thanhtri districts of Hanoi city is introduced (Nguyen et al., 1996).

\section{BACKGROUND RESEARCH}

So far some research works on the environmental status of Hanoi city in water and soils have been performed. Standards for the quality of water and for the heavy metal contents of soil in Vietnam (Ministry of Science and Environment, 1995) are shown in Tables 1 and 2, respectively. Some of background researches are outlined here.

\section{Quality of water}

River systems in Tuliem and Thanhtri districts are reproduced in Fig. 1. Water of the Red River flows into the Nhue River through the Lienmac gate. Chemical composition of the Red River at several locations is shown in Table 3 (Tran, 1996). Quality of the Nhue River is good near the gate but declines gradually by discharge of the waste water from some factories and after flowing-in of the Tolich and Kimnguu Rivers. The Nhue River irrigates most of the agricultural land of Tuliem district (Taytuu, Minhkhai, Phudien, Xuanphuong and Taymo communes, and a part of Yenhoa and Mydinh communes).

The Tolich River begins at the West Lake and flows into the Nhue River after flowing of $13 \mathrm{~km}$. The Tolich River irrigates the agricultural land of Yenhoa and Mydinh communes of the southwestern part of Tuliem district and Thanhliet and Daikim communes of the northern part of Thanhtri district. Along the Tolich River traffic roads run, and 


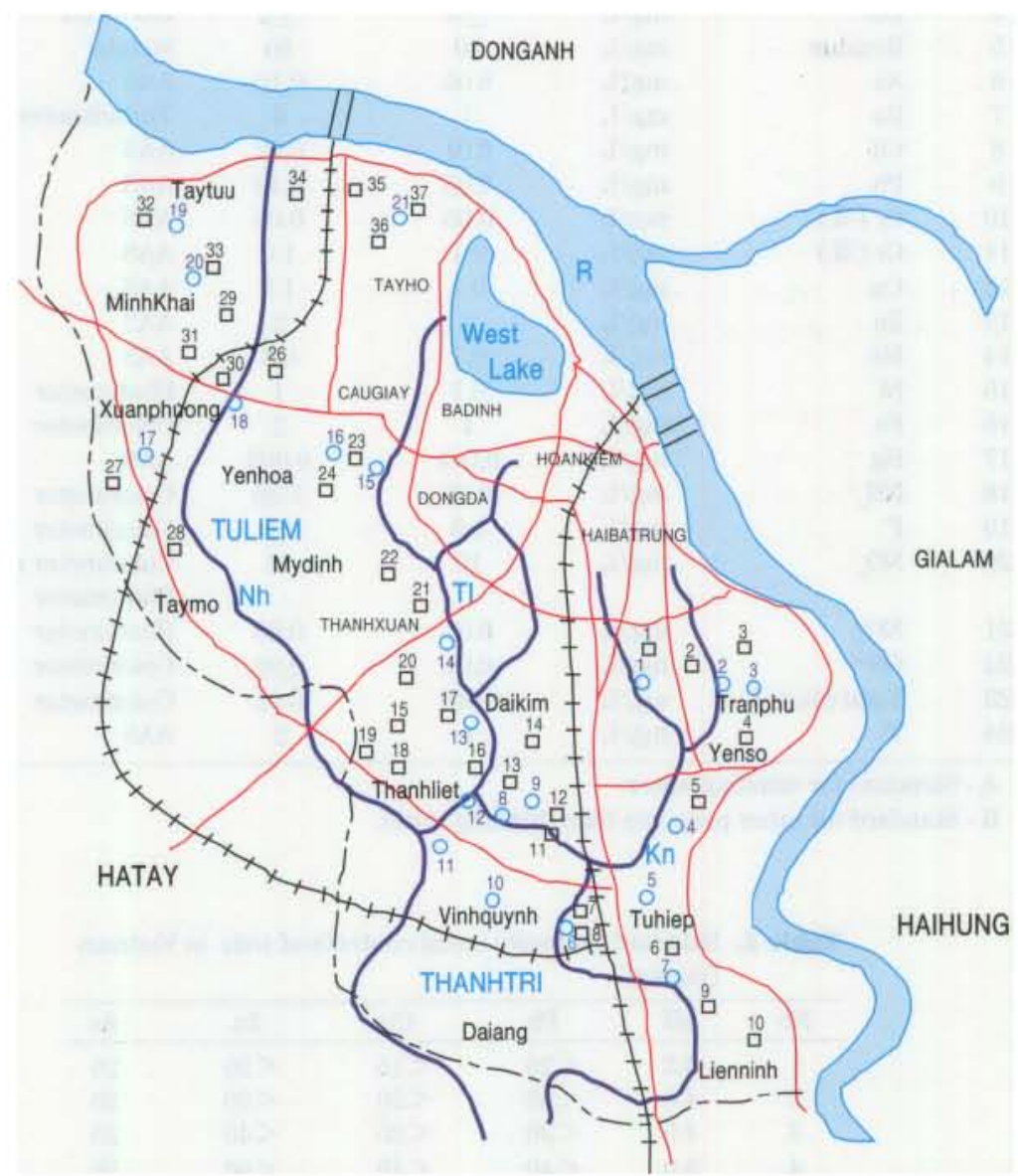

Fig. 1. River systems and sampling sites of water and soils in Tuliem and Thanhtri districts, Hanoi city.

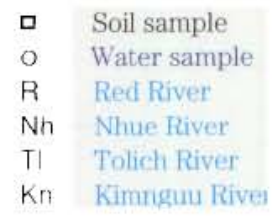


Table 1. Standard for the quality of water in Vietnam.

\begin{tabular}{|c|c|c|c|c|c|}
\hline \multirow{2}{*}{ No } & \multirow[t]{2}{*}{ Parameter } & \multirow[t]{2}{*}{ Unit } & \multicolumn{2}{|c|}{ Limit value } & \multirow[t]{2}{*}{ Determination method } \\
\hline & & & A & B & \\
\hline 1 & $\mathrm{pH}$ & & $6.6-8.5$ & $5.5-9.0$ & $\mathrm{pH}$ meter \\
\hline 2 & $\mathrm{BOD}_{5}\left(20^{\circ} \mathrm{C}\right)$ & $\mathrm{mg} / \mathrm{L}$ & 4 & 25 & \\
\hline 3 & $\mathrm{COD}$ & $\mathrm{mg} / \mathrm{L}$ & 10 & 35 & Oxidation with $\mathrm{K}_{2} \mathrm{Cr}_{2} \mathrm{O}_{2}$ \\
\hline 4 & DO & $\mathrm{mg} / \mathrm{L}$ & $\geq 6$ & $\geq 2$ & DO meter \\
\hline 5 & Residue & $\mathrm{mg} / \mathrm{L}$ & $\overline{20}$ & 80 & Weight \\
\hline 6 & As & $\mathrm{mg} / \mathrm{L}$ & 0.05 & 0.10 & AAS \\
\hline 7 & $\mathrm{Ba}$ & $\mathrm{mg} / \mathrm{L}$ & 1 & 4 & Turbidimeter \\
\hline 8 & $\mathrm{Cd}$ & $\mathrm{mg} / \mathrm{L}$ & 0.01 & 0.02 & AAS \\
\hline 9 & $\mathrm{~Pb}$ & $\mathrm{mg} / \mathrm{L}$ & 0.05 & 0.10 & AAS \\
\hline 10 & $\mathrm{Cr}(\mathrm{V})$ & $\mathrm{mg} / \mathrm{L}$ & 0.05 & 0.05 & AAS \\
\hline 11 & $\mathrm{Cr}(\mathbb{I I})$ & $\mathrm{mg} / \mathrm{L}$ & 0.1 & 1.0 & AAS \\
\hline 12 & $\mathrm{Cu}$ & $\mathrm{mg} / \mathrm{L}$ & 0.1 & 1.0 & AAS \\
\hline 13 & $\mathrm{Zn}$ & $\mathrm{mg} / \mathrm{L}$ & 1 & 2 & AAS \\
\hline 14 & $\mathrm{Mn}$ & $\mathrm{mg} / \mathrm{L}$ & 0.1 & 0.8 & AAS \\
\hline 15 & $\mathrm{Ni}$ & $\mathrm{mg} / \mathrm{L}$ & 0.1 & 1 & Photometer \\
\hline 16 & $\mathrm{Fe}$ & $\mathrm{mg} / \mathrm{L}$ & 1 & 2 & Colorimeter \\
\hline 17 & $\mathrm{Hg}$ & $\mathrm{mg} / \mathrm{L}$ & 0.001 & 0.002 & AAS \\
\hline 18 & $\mathrm{NH}_{+}^{-}$ & $\mathrm{mg} / \mathrm{L}$ & 0.05 & 1.00 & Colorimeter \\
\hline 19 & $\mathrm{~F}^{-}$ & $\mathrm{mg} / \mathrm{L}$ & 1.0 & 1.5 & Colorimeter \\
\hline 20 & $\mathrm{NO}_{3}^{-}$ & $\mathrm{mg} / \mathrm{L}$ & 10 & 15 & $\begin{array}{l}\text { Colorimeter and } \\
\text { Photometer }\end{array}$ \\
\hline 21 & $\mathrm{NO}_{2}$ & $\mathrm{mg} / \mathrm{L}$ & 0.01 & 0.05 & Photometer \\
\hline 22 & $\mathrm{CN}^{2}$ & $\mathrm{mg} / \mathrm{L}$ & 0.01 & 0.05 & Colorimeter \\
\hline 23 & Total phenol & $\mathrm{mg} / \mathrm{L}$ & 0.001 & 0.02 & Colorimeter \\
\hline 24 & $\mathrm{Ti}$ & $\mathrm{mg} / \mathrm{L}$ & 1 & 2 & AAS \\
\hline
\end{tabular}

A - Standard for drinking water.

B - Standard for other purposes than drinking water.

Table 2. Standard for heavy metal contents of soils in Vietnam

\begin{tabular}{ccrrrr}
\multicolumn{7}{c}{$(\mathrm{mg} / \mathrm{kg})$} & & & \\
\hline No & $\mathrm{pH}$ & $\mathrm{Pb}$ & $\mathrm{Cu}$ & $\mathrm{Zn}$ & As \\
\hline 1 & 3.5 & $<20$ & $<15$ & $<20$ & 25 \\
2 & 4.0 & $<25$ & $<20$ & $<30$ & 25 \\
3 & 4.5 & $<30$ & $<25$ & $<40$ & 25 \\
4 & 5.0 & $<40$ & $<40$ & $<60$ & 25 \\
5 & 5.5 & $<50$ & $<60$ & $<90$ & 25 \\
6 & 5.7 & $<60$ & $<80$ & $<110$ & 25 \\
7 & 6.0 & $<70$ & $<120$ & $<200$ & 25 \\
8 & 6.2 & $<75$ & $<180$ & $<300$ & 25 \\
9 & 6.5 & $<80$ & $<250$ & $<320$ & 25 \\
10 & 7.0 & 80 & 260 & 340 & 25 \\
11 & 7.5 & 80 & 270 & 360 & 25 \\
12 & 8.0 & 80 & 280 & 370 & 25 \\
\hline
\end{tabular}


Table 3. Chemical composition of the Red River.

\begin{tabular}{cllcccc}
\hline \multirow{2}{*}{ No } & Parameter & Unit & \multicolumn{4}{c}{ Location } \\
\cline { 4 - 6 } & & & $\begin{array}{c}\text { Vinhphu } \\
\text { province }\end{array}$ & $\begin{array}{c}\text { Vinhphu } \\
\text { province }\end{array}$ & $\begin{array}{c}\text { Hatay } \\
\text { province }\end{array}$ & $\begin{array}{l}\text { Hanoi } \\
\text { city }\end{array}$ \\
\hline 1 & $\mathrm{pH}$ & & $3.8-4.4$ & $7.7-8.5$ & 7.2 & 7.2 \\
2 & Organic matter & $\mathrm{mg} / \mathrm{L}$ & $0.4-1.0$ & $0.8-10.2$ & - & - \\
3 & $\mathrm{DO}$ & $\mathrm{mg} / \mathrm{L}$ & $6.1-8.2$ & $6.1-8.2$ & - & - \\
4 & $\mathrm{NO}^{-}$ & $\mathrm{mg} / \mathrm{L}$ & $0.05-0.08$ & $0.00-0.01$ & - & - \\
5 & $\mathrm{NO}_{3}$ & $\mathrm{mg} / \mathrm{L}$ & $0.02-1.00$ & $0.04-0.08$ & - & - \\
6 & $\mathrm{Na}^{+}$and $\mathrm{K}^{+}$ & $\mathrm{mg} / \mathrm{L}$ & - & - & 11.5 & 11.4 \\
7 & $\mathrm{Ca}^{2-}$ & $\mathrm{mg} / \mathrm{L}$ & - & - & 25.6 & 26.5 \\
8 & $\mathrm{Mg}^{2+}$ & $\mathrm{mg} / \mathrm{L}$ & - & - & 6.19 & 6.26 \\
9 & $\mathrm{Fe}_{10}$ & $\mathrm{mg} / \mathrm{L}$ & $4.0-100$ & $0.16-0.24$ & 0.66 & 0.58 \\
11 & $\mathrm{HCO}^{-1}$ & $\mathrm{mg} / \mathrm{L}$ & $5.2-42.6$ & $5.0-81.6$ & 5.7 & 5.2 \\
12 & $\mathrm{SO}_{4}{ }^{2}$ & $\mathrm{mg} / \mathrm{L}$ & - & - & 115 & 116 \\
13 & $\mathrm{SiO}^{-}$ & $\mathrm{mg} / \mathrm{L}$ & $47.5-84.5$ & $30.7-54.7$ & 7.7 & 8.2 \\
14 & $\mathrm{Alkalinity}^{-}$ & $\mathrm{mg} / \mathrm{L}$ & - & - & 13.5 & 13.4 \\
\hline
\end{tabular}

Table 4. Parameters relating to the quality of water of the Tolich River.

\begin{tabular}{cllcc}
\hline No & Parameter & Unit & \multicolumn{2}{c}{ Location } \\
\cline { 4 - 5 } & & & Caumoi & Kimgiang \\
\hline 1 & Turbidity & $\mathrm{cm}$ & 45 & 42 \\
2 & $\mathrm{pH}$ & & 7.7 & 7.5 \\
3 & Residues & $\mathrm{mg} / \mathrm{L}$ & 570 & 545 \\
4 & $\mathrm{COD}$ & $\mathrm{mg} / \mathrm{L}$ & 113 & 242 \\
5 & $\mathrm{BOD}_{\overline{5}}$ & $\mathrm{mg} / \mathrm{L}$ & 24.4 & 17.4 \\
6 & $\mathrm{NO}_{2}$ & $\mathrm{mg} / \mathrm{L}$ & 0.39 & 0.66 \\
7 & $\mathrm{NH}_{4}{ }^{+}$ & $\mathrm{mg} / \mathrm{L}$ & 17.4 & 9.7 \\
8 & $\mathrm{DO}$ & $\mathrm{mg} / \mathrm{L}$ & 2.0 & 3.0 \\
9 & $\mathrm{H}_{2} \mathrm{~S}$ & $\mathrm{mg} / \mathrm{L}$ & 29.8 & - \\
\hline
\end{tabular}

Buoi, Caugiay, Trunghoa and Nhanchinh markets are in operation. Besides, industrial and municipal wastes flow into the Tolich River to deteriorate the river water. The Tolich River is provided with $2,900 \mathrm{~m}^{3} /$ day of urban waste water and $22,000 \mathrm{~m}^{3} /$ day of industrial waste water from 33 factories (Nguyen, 1997). Parameters relating to the quality of water of the Tolich River measured at two locations are given in Table 4, quoted from Tran (1996). Quality of the Tolich River is extraordinarily bad. Pollution or eutrophication and reduction of water is proceeding. Comparison of the values in Table 4 with the standard for the quality of water (Table 1) indicates that six parameters of residues, COD, BOD, $\mathrm{NO}_{2}, \mathrm{NH}_{4}{ }^{+}$and $\mathrm{DO}$ are exceedingly over the limit for drinking water at the two locations. From the viewpoint of the quality as the agricultural water, high concentrations of $\mathrm{NH}_{4}{ }^{+}$ and $H_{2} \mathrm{~S}$ may have adverse effects on the crop growth. 
The Kimnguu River begins to flow in the densely populated area of Hanoi city like the Tolich River. It irrigates the agricultural land of Tranphu and Yenso communes, before meeting the Tolich River. The river then irrigates the agricultural land of Tuhiep and Lienninh communes. The Kimnguu River is provided with $139,000 \mathrm{~m}^{3} /$ day of urban and industrial waste water (Nguyen, 1997). Parameters relating to the quality of water of the Kimnguu River measured at four locations are given in Table 5, quoted from Tran (1996). Quality of the Kimnguu River is very bad. Pollution or eutrophication and reduction of water is proceeding. In comparison with the standard for the quality of water (Table 1), six parameters of residues, $\mathrm{DO}, \mathrm{COD}, \mathrm{BOD}_{5}, \mathrm{NH}_{4}{ }^{+}$and Fe were noticeably over the limit for drinking water at the four locations. From the viewpoint of the quality as the agricultural water, high concentrations of total $\mathrm{N}, \mathrm{NH}_{4}{ }^{+}$and $\mathrm{H}_{2} \mathrm{~S}$ may have adverse effects on the crop growth, like the Tolich River.

Table 5. Parameters relating to the quality of water of the Kimnguu River.

\begin{tabular}{|c|c|c|c|c|c|c|}
\hline \multirow[t]{2}{*}{ No } & \multirow[t]{2}{*}{ Parameter } & \multirow[t]{2}{*}{ Unit } & \multicolumn{4}{|c|}{ Location } \\
\hline & & & 1 & 2 & 3 & 4 \\
\hline 1 & Temperature & ${ }^{\circ} \mathrm{C}$ & $27-28$ & $22-27$ & $22-27$ & $22-27$ \\
\hline 2 & $\mathrm{pH}$ & & 7.0 & 7.2 & 7.1 & 7.7 \\
\hline 3 & Residues & $\mathrm{mg} / \mathrm{L}$ & 282 & 155 & 75 & 31 \\
\hline 4 & DO & $\mathrm{mg} / \mathrm{L}$ & 0.0 & 0.5 & 1.0 & 1.2 \\
\hline 5 & $\mathrm{COD}$ & $\mathrm{mg} / \mathrm{L}$ & 495 & 200 & 225 & 170 \\
\hline 6 & $\mathrm{BOD}_{5}$ & $\mathrm{mg} / \mathrm{L}$ & 129.2 & 80.2 & 70.7 & 37.4 \\
\hline 7 & Total N & $\mathrm{mg} / \mathrm{L}$ & 56.2 & 70.4 & 77.2 & 42.5 \\
\hline 8 & $\mathrm{NH}_{4}{ }^{+}$ & $\mathrm{mg} / \mathrm{L}$ & 15.8 & 11.8 & 10.9 & 5.6 \\
\hline 9 & $\mathrm{NO}_{4}^{-}$ & $\mathrm{mg} / \mathrm{L}$ & 0.0 & 0.0 & 0.0 & 0.0 \\
\hline 10 & $\mathrm{PO}_{4}^{3-}$ & $\mathrm{mg} / \mathrm{L}$ & 0.3 & 7.3 & 4.2 & 8.2 \\
\hline 11 & $\mathrm{HCO}_{3}$ & $\mathrm{mg} / \mathrm{L}$ & 390 & 403 & 445 & 420 \\
\hline 12 & $\mathrm{Cl}$ & $\mathrm{mg} / \mathrm{L}$ & 70.9 & 58.3 & 70.9 & 67.4 \\
\hline 13 & $\mathrm{SO}_{4}{ }^{2-}$ & $\mathrm{mg} / \mathrm{L}$ & 11.8 & 6.9 & 2.1 & 5.5 \\
\hline 14 & $\mathrm{Fe}$ & $\mathrm{mg} / \mathrm{L}$ & 2.5 & 2.5 & 2.5 & 6.3 \\
\hline 15 & $\mathrm{Na}^{+}$ & $\mathrm{mg} / \mathrm{L}$ & 32 & 26 & 34 & 47 \\
\hline 16 & $\mathrm{~K}^{-}$ & $\mathrm{mg} / \mathrm{L}$ & 23.0 & 7.0 & 7.4 & 10.0 \\
\hline 17 & $\mathrm{H}_{2} \mathrm{~S}$ & $\mathrm{mg} / \mathrm{L}$ & 9.1 & 11.0 & 7.8 & 2.6 \\
\hline
\end{tabular}

Table 6. Contents of heavy metals in agricultural soils of Vandien area (mg/kg).

\begin{tabular}{clcccc} 
No & \multicolumn{1}{c}{ Location } & $\mathrm{Cu}$ & $\mathrm{Mn}$ & $\mathrm{Zn}$ & $\mathrm{Pb}$ \\
\hline 1 & $\begin{array}{l}\text { In front of Vandien battery factory } \\
2\end{array}$ & 18.7 & 173 & 30.6 & 17.5 \\
& $\begin{array}{l}\text { Area under influence of Vandien } \\
\text { battery factory and Vandien } \\
\text { phosphate factory }\end{array}$ & 49.7 & 305 & 1341 & 24.7 \\
3 & $\begin{array}{l}\text { Area under no influence of chemical } \\
\text { experimental manufactory }\end{array}$ & 21.2 & 251 & 25.1 & 25.7 \\
4 & $\begin{array}{l}\text { Area under influence of chemical } \\
\text { experimental manufactory } \\
\text { Area between Vandien phosphate } \\
\text { factory and chemical experimental } \\
\text { manufactory }\end{array}$ & 12.9 & 1413 & 177 & 55.4 \\
& & 2017 & 249 & 62.2 \\
\hline
\end{tabular}




\section{Quality of agricultural soils}

Now in Hanoi, attention has been increasingly paid to the contamination of agricultural soil with heavy metals.

Contents of heavy metals in agricultural soils of Vandien area measured at five locations are given in Table 6, quoted from Pham et al. (1995). According to the standard for heavy metal contents of soils (Table 2), values of 50,60 and 90 can be taken as the minimum limits for $\mathrm{Pb}, \mathrm{Cu}$ and $\mathrm{Zn}$, respectively, because most soils in this area had the $\mathrm{pH}$ of more than 5.5 (Tables 10 and 11). Among the five locations, only two locations of No. 1 and No. 3 were below the limit for all the three heavy metals, whereas locations of No. 4 and No. 5 were over the limit for $\mathrm{Pb}$ and $\mathrm{Zn}$. Location of No. 2 showed the very high concentration of $\mathrm{Zn}$. Pollution of agricultural soils by $\mathrm{Zn}$ and $\mathrm{Pb}$ were indicated to be severe in Vandien area.

\section{STUDY AREA}

Study area is Tuliem and Thanhtri districts which have total area of 20,282 ha, in which cropped area is 8,776 ha. Agricultural soils are classified as neutral alluvium (P) and neutral alluvium with gley layer (Pg). Main crops are rice and vegetables, which are supplied to Hanoi city all the year round. Recently farmers use less organic manure and much pesticide.

Agricultural water is provided from the Nhue River system. Quality of water of the Nhue River is not uniform from Lienmac gate to Dongmy pumping station, because the Nhue River is connecting to the Tolich and Kimnguu Rivers as well as the Red River.

Based on the Vietnam standard for the quality of water and soils, 14 water and 22 soil samples in Thanhtri district, and 7 water and 14 soil samples in Tuliem district were colleted. Sampling sites are shown in Fig. 1 and recorded in the following.

Locations of water sampling in Thanhtri district:

1. Water of the Kimnguu River in Hoangvanthu commune.

2. Water of the Kimnguu River at the gate into the Yenso Lake.

3. Water of the Yenso Lake (rice and fish).

4. Waste water from the Kimnguu River in Vuhiep commune.

5. Waste water of irrigation canal beside Ngochoi hospital.

6. Irrigation water to the experimental farm of Institute of Agricultural Science Vietnam.

7. Water of the Tolich River in Tuhiep commune.

8. Mixed water of the Tolich River and waste water of Vandien battery factory.

9. Waste water of Vandien phosphate factory.

10. Water in the field behind Vandien cemetery.

11. Water in the field at To bridge from the Nhue River.

12. Water of the Tolich River near Hanoi painting factory.

13. Urban waste water providing for vegetables near Kimgiang collective zone.

14. Water of the Tolich River near Saovang rubber factory and Hanoi soap factory.

Locations of water sampling in Tuliem districts:

15. Water of the Tolich River at Yenhoa bridge.

16. Water of the Yenhoa canal behind Smith building.

17. Water of the pond system in Xuanphuong commune . 
18. Water of the Nhue River at Dien bridge.

19. Water of the Taytuu canal connecting to the Nhue River.

20. Water of the irrigation canal near Tuliem orchard in Minhkhai commune.

21. Water of the Conhue canal connecting to the Nhue River.

Locations of soil sampling in Thanhtri district:

1. Spinach field on the right side of Highway $1 \mathrm{~A}$ in Hoangvanthu commune.

2. Rice field on the left side of Highway 1A in Hoangvanthu commune.

3. Rice-fish field in Yenso commune.

4. Rice-vegetable field in Vuhiep commune.

5. Rice field in Vuhiep commune.

6. Rice field in Lienninh commune.

7. Rice-vegetable field in the high experimental area of Institute of Agricultural Science Vietnam.

8. Rice-vegetable field in the low experimental area of Institute of Agricultural Science Vietnam.

9. Spinach field in Tuhiep commune.

10. Vegetable field near the Tolich River on the left side of Highway 1A in Tuhiep commune.

11. Sewage sludge of the Tolich River.

12. Vegetable field between the right side of Vandien battery factory and the left side of Vandien phosphate factory.

13. Vegetable field irrigated by waste water from Vandien phosphate factory.

14. Rice field on the right side of Vandien phosphate factory.

15. Rice field in Tathanhoai commune.

16. Vegetable field near the Tolich River in Thanhliet commune.

17. Rice field $800 \mathrm{~m}$ distant from Thanhliet Administrative Committee in Thanhliet commune.

18. Rice field near Highway 6 in front of Institute of Malaria.

19. Spinach field near Highway 6 in front of Institute of Malaria.

20. Vegetable field near Saovang rubber factory, Hanoi soap factory, and Thanglong tobacco factory in Tantrung commune.

21. Rice field near drain of the Tolich River in Dinhcong commune.

22. Vegetable field near drain of the Tolich River in Dinhcong commune.

Locations of soil sampling in Tuliem district:

23. Rice field $600 \mathrm{~m}$ behind Smith building in Hoaiduc commune.

24. Vegetable field near 19-8 hospital in Mydinh commune.

26. Xa rice field behind SOS.

27. Rice field in Xuanphuong commune.

28. Rice field near the Nhue River in Xuanphuong commune.

29. Vegetable field $200 \mathrm{~m}$ distant from Phudien station in Phudien commune.

30. Rice field $100 \mathrm{~m}$ distant from Hanoi paint factory in Phudien commune.

31. Vegetable field near Highway 70 in Nhon village.

32. Rice-vegetable field near Highway 70 in Taytuu commune.

33. Vegetable field $3 \mathrm{~km}$ distant from Nhon in Minhkhai commune.

34. Rice field in Dongngac commune.

35. Rice field near Thanglong bridge in Dongngac commune.

36. Rice field in Xuandinh commune. 
37. Rice-vegetable field in Conhue commune.

\section{ANALYTICAL METHODS AND DATA}

Following parameters and analytical methods or instruments were assessed for the analysis of water and soil samples.

$\mathrm{pH}: \mathrm{pH}$ meter.

Total N: Kjeldhal method.

Organic C: Walkley and Black method.

Total $\mathrm{P}_{2} \mathrm{O}_{5}$ : colorimetric method by molydenum compound.

Available $\mathrm{P}_{3} \mathrm{O}_{5}$ : Bray method.

Water-soluble $\mathrm{Cl}$ : argentometric titration.

Electric conductivity: conductivity meter.

COD: oxidation with $\mathrm{K}_{2} \mathrm{Cr}_{2} \mathrm{O}_{7}$.

Total number of coliform: according to Draft International Standard ISO/DIS 4831.

Heavy metals ( $\mathrm{Cu}, \mathrm{Zn}, \mathrm{Pb}$, Cd): volt-ampere striping method and atomic absorption spectrophotometer.

Data obtained are shown in Tables 7 to 9 for water samples and in Tables 10 to 12 for soil samples.

Table 7. Analytical results for water samples in Thanhtri district.

\begin{tabular}{cccccc}
\hline $\begin{array}{c}\text { Sample } \\
\text { No }\end{array}$ & $\mathrm{pH}$ & $\begin{array}{c}\mathrm{EC} \\
(\mathrm{dS} / \mathrm{m})\end{array}$ & $\begin{array}{c}\text { Total salt } \\
(\%)\end{array}$ & $\begin{array}{c}\mathrm{COD} \\
(\mathrm{mg} / \mathrm{L})\end{array}$ & $\begin{array}{c}\text { Total coliform } \\
(\mathrm{col} / 100 \mathrm{~mL})\end{array}$ \\
\hline 1 & 7.05 & 0.56 & 0.36 & 27.4 & - \\
2 & 7.10 & 0.45 & 0.29 & 24.8 & - \\
3 & 7.15 & 0.39 & 0.25 & 20.2 & $2000-4000$ \\
4 & 7.40 & 0.40 & 0.26 & 24.8 & - \\
5 & 7.15 & 0.22 & 0.14 & 21.5 & - \\
6 & 7.36 & 0.59 & 0.38 & 20.8 & $2000-4000$ \\
7 & 7.25 & 0.40 & 0.26 & 12.7 & - \\
8 & 6.90 & 0.35 & 0.22 & 10.9 & $90-1800$ \\
9 & 7.44 & 0.28 & 0.18 & 9.5 & - \\
10 & 7.52 & 0.30 & 0.19 & 10.5 & - \\
11 & 7.15 & 0.30 & 0.19 & - & - \\
12 & 6.90 & 0.42 & 0.27 & 14.5 & $90-940$ \\
13 & 7.47 & 0.50 & 0.32 & 10.6 & $900-19800$ \\
14 & 7.30 & 0.45 & 0.29 & 12.5 & $900-19800$ \\
\hline
\end{tabular}

Table 8. Analytical results for water samples in Tuliem district.

\begin{tabular}{cccccc}
\hline $\begin{array}{c}\text { Sample } \\
\text { No }\end{array}$ & $\mathrm{pH}$ & $\begin{array}{c}\mathrm{EC} \\
(\mathrm{dS} / \mathrm{m})\end{array}$ & $\begin{array}{c}\text { Total salt } \\
(\%)\end{array}$ & $\begin{array}{c}\text { COD } \\
(\mathrm{mg} / \mathrm{L})\end{array}$ & $\begin{array}{c}\text { Total coliform } \\
(\text { col/100 mL) }\end{array}$ \\
\hline 15 & 7.42 & 0.50 & 0.32 & 22.4 & $1000-20000$ \\
16 & 7.10 & 0.25 & 0.16 & 10.5 & - \\
17 & 7.20 & 0.28 & 0.18 & 9.8 & - \\
18 & 7.31 & 0.18 & 0.12 & 15.7 & $180-3600$ \\
19 & 7.30 & 0.25 & 0.16 & - & - \\
20 & 7.10 & 0.35 & 0.22 & 28.5 & $180-3600$ \\
21 & 7.35 & 0.51 & 0.33 & 7.8 & - \\
\hline
\end{tabular}


Table 9. Contents of heavy metals in water samples in Thanhtri and Tuliem districts (mg/L).

\begin{tabular}{ccccc}
\hline $\begin{array}{c}\text { Sample } \\
\text { No }\end{array}$ & $\mathrm{Zn}$ & $\mathrm{Cd}$ & $\mathrm{Pb}$ & $\mathrm{Cu}$ \\
\hline 2 & 0.430 & 0.0007 & 0.020 & 0.807 \\
4 & 0.100 & 0.0004 & 0.413 & 0.187 \\
5 & 0.100 & 0.0004 & 0.385 & 0.192 \\
6 & 0.058 & 0.0002 & 0.026 & 0.233 \\
8 & 0.339 & 0.0236 & 0.007 & 0.039 \\
9 & 0.401 & 0.0035 & 0.034 & 7.413 \\
12 & 0.331 & 0.0041 & 0.021 & 0.038 \\
13 & 0.425 & 0.0148 & 0.022 & 0.049 \\
15 & 0.409 & 0.0005 & 0.024 & 0.062 \\
18 & 0.210 & 0.0009 & 0.040 & 0.048 \\
20 & 0.108 & 0.0326 & 0.158 & 0.131 \\
\hline
\end{tabular}

Table 10. Analytical results for soil samples in Thanhtri district.

\begin{tabular}{cccccccc}
\hline $\begin{array}{c}\text { Sample } \\
\text { No }\end{array}$ & $\begin{array}{c}\mathrm{pH}(\mathrm{KCl}) \\
\text { Organic C } \\
(\%)\end{array}$ & $\begin{array}{c}\text { Total } \mathrm{N} \\
(\%)\end{array}$ & $\begin{array}{c}\text { Total } \mathrm{P}_{3} \mathrm{O}_{5} \\
(\%)\end{array}$ & $\begin{array}{c}\text { Available } \\
\mathrm{P}_{2} \mathrm{O}_{5} \\
(\mathrm{mg} / 100 \mathrm{~g})\end{array}$ & $\begin{array}{c}\mathrm{EC} \\
(\mathrm{dS} / \mathrm{m})\end{array}$ & $\begin{array}{c}\mathrm{Cl}^{-} \\
(\%)\end{array}$ \\
\hline 1 & 6.65 & 1.15 & 0.17 & 0.24 & 13.1 & 0.80 & 0.021 \\
2 & 6.82 & 1.55 & 0.25 & 0.19 & 7.8 & 0.68 & 0.017 \\
3 & 6.92 & 1.10 & 0.15 & 0.22 & 4.8 & 1.00 & 0.027 \\
4 & 6.60 & 1.25 & 0.16 & 0.21 & 6.1 & 0.44 & 0.021 \\
5 & 6.45 & 2.10 & 0.17 & 0.18 & 4.8 & 0.64 & 0.017 \\
6 & 6.18 & 2.05 & 0.13 & 0.10 & 2.0 & 0.36 & 0.014 \\
7 & 6.33 & 1.00 & 0.08 & 0.13 & 2.6 & 0.32 & 0.021 \\
8 & 5.45 & 1.60 & 0.24 & 0.16 & 3.5 & 0.52 & 0.010 \\
9 & 5.60 & 2.20 & 0.24 & 0.19 & 3.2 & 0.36 & 0.021 \\
10 & 6.30 & 1.20 & 0.13 & 0.20 & 4.8 & 0.72 & 0.025 \\
11 & 7.00 & 2.00 & 0.22 & 0.24 & 5.8 & 2.44 & 0.017 \\
12 & 6.67 & 2.30 & 0.24 & 0.21 & 2.8 & 0.72 & 0.010 \\
13 & 6.96 & 1.50 & 0.11 & 0.44 & 35.0 & 2.04 & 0.020 \\
14 & 6.50 & 1.50 & 0.18 & 0.31 & 3.0 & 0.60 & 0.014 \\
15 & 6.13 & 2.00 & 0.25 & 0.24 & 5.8 & 0.56 & 0.010 \\
16 & 6.22 & 0.80 & 0.08 & 0.15 & 3.5 & 0.28 & 0.014 \\
17 & 5.78 & 1.45 & 0.18 & 0.18 & 4.8 & 0.40 & 0.010 \\
18 & 5.65 & 2.50 & 0.16 & 0.15 & 3.8 & 0.28 & 0.017 \\
19 & 5.70 & 1.45 & 0.17 & 0.12 & 2.0 & 0.32 & 0.014 \\
20 & 5.60 & 1.05 & 0.17 & 0.17 & 4.2 & 0.48 & 0.014 \\
21 & 5.66 & 1.75 & 0.22 & 0.16 & 2.6 & 0.36 & 0.014 \\
22 & 6.33 & 1.15 & 0.17 & 0.19 & 10.4 & 0.52 & 0.010 \\
\hline
\end{tabular}


Table 11. Analytical results for soil samples in Tuliem district.

\begin{tabular}{cccccccc}
\hline $\begin{array}{c}\text { Sample } \\
\text { No }\end{array}$ & pH(KCl) & $\begin{array}{c}\text { Organic } \mathrm{C} \\
(\%)\end{array}$ & $\begin{array}{c}\text { Total } \mathrm{N} \\
(\%)\end{array}$ & $\begin{array}{c}\text { Total } \mathrm{P}_{2} \mathrm{O}_{5} \\
(\%)\end{array}$ & $\begin{array}{c}\text { Available } \\
\mathrm{P}_{2} \mathrm{O}_{5} \\
(\mathrm{mg} / 100 \mathrm{~g})\end{array}$ & $\begin{array}{c}\mathrm{EC} \\
(\mathrm{dS} / \mathrm{m})\end{array}$ & $\begin{array}{c}\mathrm{Cl}^{-} \\
(\%)\end{array}$ \\
\hline 23 & 6.38 & 1.60 & 0.16 & 0.12 & 2.0 & 0.32 & 0.017 \\
24 & 6.01 & 1.75 & 0.24 & 0.19 & 7.1 & 0.32 & 0.014 \\
26 & 6.27 & 1.20 & 0.15 & 0.17 & 6.1 & 0.32 & 0.014 \\
27 & 5.68 & 2.00 & 0.17 & 0.14 & 2.0 & 0.36 & 0.010 \\
28 & 6.93 & 2.20 & 0.18 & 0.15 & 2.0 & 0.72 & 0.014 \\
29 & 6.75 & 1.30 & 0.18 & 0.19 & 4.5 & 0.32 & 0.014 \\
30 & 6.27 & 1.75 & 0.16 & 0.15 & 3.1 & 0.24 & 0.010 \\
31 & 6.75 & 2.00 & 0.15 & 0.11 & 2.0 & 0.19 & 0.010 \\
32 & 6.27 & 2.00 & 0.20 & 0.13 & 2.6 & 0.24 & 0.007 \\
33 & 5.70 & 1.75 & 0.17 & 0.21 & 8.8 & 0.64 & 0.014 \\
34 & 5.40 & 1.25 & 0.17 & 0.11 & 2.2 & 0.16 & 0.007 \\
35 & 6.75 & 1.80 & 0.24 & 0.15 & 3.8 & 0.36 & 0.007 \\
36 & 5.40 & 1.35 & 0.11 & 0.13 & 2.8 & 0.16 & 0.007 \\
37 & 6.75 & 2.30 & 0.12 & 0.16 & 3.6 & 0.36 & 0.007 \\
\hline
\end{tabular}

Table 12. Contents of heavy metals in soil samples in Thanhtri and Tuliem districts $(\mathrm{mg} / \mathrm{kg})$.

\begin{tabular}{ccccc}
\hline $\begin{array}{c}\text { Sample } \\
\text { No }\end{array}$ & $\mathrm{Zn}$ & $\mathrm{Cu}$ & $\mathrm{Pb}$ & $\mathrm{Cd}$ \\
\hline 2 & 89.9 & 33.1 & 3.50 & 0.24 \\
3 & 36.4 & 12.1 & 0.49 & 0.08 \\
7 & 59.2 & 25.0 & 0.19 & 0.21 \\
11 & 2541 & 41.5 & 7.73 & 1.20 \\
13 & 1164 & 36.3 & 15.73 & 1.33 \\
16 & 44.6 & 17.5 & 2.53 & 0.37 \\
19 & 74.4 & 23.1 & 1.39 & 0.09 \\
24 & 61.9 & 29.8 & 1.45 & 0.40 \\
26 & 36.2 & 16.4 & 0.47 & 0.14 \\
30 & 40.9 & 26.7 & 0.22 & 0.17 \\
31 & 22.5 & 12.7 & 0.58 & 0.12 \\
32 & 41.5 & 30.4 & 0.54 & 0.16 \\
33 & 61.5 & 70.4 & 0.49 & 0.22 \\
37 & 39.2 & 20.7 & 0.82 & 0.28 \\
\hline
\end{tabular}




\section{QUALITY OF WATER}

Based on the analytical results (Tables 7 to 9) and in comparison with the Vietnam standard for the quality of water (Table 1), quality of water as the agricultural use in Tuliem and Thanhtri districts was evaluated.

$\mathrm{pH}$ : most water samples were neutral.

EC (electric conductivity): EC was between 0.18 and $0.59 \mathrm{dS} / \mathrm{m}$. It was related with the content of total salt (\%) with a equation of total salt=0.64 x EC.

COD (chemical oxygen demand): COD was between 7.8 and $28.5 \mathrm{mg} / \mathrm{L}$. According to the Vietnam standard the limit value of COD for irrigation water is $35 \mathrm{mg} / \mathrm{L}$. COD of water in Tuliem and Thanhtri districts was below this limit.

According to the Vietnam standard the limit values for $\mathrm{Zn}, \mathrm{Cu}, \mathrm{Pb}$ and $\mathrm{Cd}$ are 2, 1.0, 0.10 and $0.02 \mathrm{mg} / \mathrm{L}$, respectively, as agricultural use.

Zn: no water sample was over the limit.

$\mathrm{Cu}$ : only waste water of Vandien phosphate factory was over the limit.

$\mathrm{Pb}$ : three samples exceeded the limit. They were waste water from the Kimnguu River in Vuhiep commune, waste water of irrigation canal beside Ngochoi hospital, and water of the irrigation canal near Tuliem orchard in Minhkhai commune.

Cd: two samples exceeded the limit. They were mixed water of the Tolich River and waste water of Vandien battery factory, and water of the irrigation canal near Tuliem orchard in Minhkhai commune.

Contamination with different heavy metals, in addition to eutrophication and reduction as described in BACKGROUND RESEARCH, is proceeding in water of Tuliem and Thanhtri districts.

\section{QUALITY OF AGRICULTURAL SOILS}

Based on the analytical results (Tables 10 to 12), quality of agricultural soils in Tuliem and Thanhtri districts was evaluated.

$\mathrm{pH}$ : pH ranged from 5.40 to 7.00 . Most of samples (70\%) was in 6.0-7.0. Now pH is higher than $\mathrm{pH}$ of several years ago, and hence quality of soil has been improved in $\mathrm{pH}$.

Total N: all soil samples showed the total $\mathrm{N}$ content below $0.25 \%$, indicating the generally poor status of $\mathrm{N}$. This tendency can be ascribed to decreasing application of organic manure and intensified crop production.

Available $\mathrm{P}$ : the values of $20-50$ and $>50 \mathrm{mg} / \mathrm{kg}$ as $\mathrm{P}_{2} \mathrm{O}_{5}$ are roughly evaluated to be medium and high, respectively, in available $\mathrm{P}$ by the Bray methods (Olsen and Sommers, 1982). All samples had available $\mathrm{P}_{2} \mathrm{O}_{5}$ more than $20 \mathrm{mg} / \mathrm{kg}$, and some samples showed the quite high values, probably affected by the irrigation of agricultural water having high water-soluble $P$.

According to the Vietnam standard for heavy metal contents of soils (Table 2), two soil samples of sewage sludge of the Tolich River (sample No. 11) and vegetable field irrigated by waste water from Vandien phosphate factory (sample No. 13) extraordinarily exceeded the minimum limit for $\mathrm{Zn}$. They were also contaminated with $\mathrm{Cu}, \mathrm{Pb}$ and $\mathrm{Cd}$. Mud of the river bed in the Nhue River system is suggested to be accumulated with the different heavy metals. In addition to sample Nos. 11 and 13 , soil sample of vegetable field $3 \mathrm{~km}$ distant from Nhon in Minhkhai commune (sample No. 33) showed the $\mathrm{Cu}$ 
content nearly equal to the minimum limit.

According to Lindsay (1979), common ranges of $\mathrm{Zn}, \mathrm{Cu}, \mathrm{Pb}$ and $\mathrm{Cd}$ in soils are $10-300,2-100,2-200$ and $0.01-0.07 \mathrm{mg} / \mathrm{kg}$, respectively. Comparing these ranges with the determined values of Table 12, it was indicated that $\mathrm{Zn}$ and $\mathrm{Cd}$ contents of sample Nos. 11 and 13 exceeded the common range for soils and that $\mathrm{Pb}$ content was underestimated as a whole.

Pollution of water and agricultural soils by heavy metals appear to be in advance in Tuliem and Thanhtri districts. Waste water from manufacturing factories and agricultural chemicals are considered as possible sources of heavy metal pollution. Effect of transportation on the pollution of water and soil was not clear.

\section{REFERENCES}

Hanoi Statistical Office 1996 Statistical Yearbook, Hanoi (in Vietnamese)

Lindsay, W. L. 1979 Chemical Equilibria in Soils. Wiley-Interscience Publication, New York, pp. 6-8

Ministry of Science and Environment 1995 The Standard for the Quality of Water and Soils. Hanoi (in Vietnamese)

Nguyen Dinh Manh, Ho Thi Lam Tra, Do Nguyen Hai and Hoang Hai Ha 1996 Report: Estimation of Actual Pollution of Agricultural Water and Soils in Hanoi. Hanoi Scientific and Environmental Office, Hanoi (in Victnamese)

Nguyen Van Khien 1997 Report: Environmental Pollution in Hanoi. Hanoi Scientific and Environmental Office, Hanoi (in Vietnamese)

Olsen, S, R. and L. E. Sommers 1982 Phosphorus. In "Methods of Soil Analysis Part 2", ed. by A. L. Page, P. H. Miller and D. R. Keeney, American Society of Agronomy, Inc. and Soil Science Society of America, Inc., Madison, Wisconsin, pp. 403-430

Pham Binh Quyen, Nguyen Van San and Tran Ngoc Lam 1995 Results of Initial Study on Pollution of Heavy Metals in Residents and Agricultural Soils by Industrial Production. Environmental Information, pp. 1-3 (in Vietnamese)

Tran Duy Kieu 1996 Evaluation of Hanoi Water Resources. Ph.D. thesis of Hanoi National University, Hanoi, pp. 33-38 (in Vietnamese) 